\title{
Cystic Fibroadenoma of the Breast: A Case Report
}

\section{Memenin Kistik Fibroadenomu: Olgu Sunumu}

\author{
Merih GÜRAY DURAK ${ }^{1}$, Ilgın KARAMAN' ${ }^{1}$, Tülay CANDA ${ }^{1}$, Pınar BALCI², Ömer HARMANCIOĞLU ${ }^{3}$
}

Departments of ${ }^{1}$ Pathology, ${ }^{2}$ Radiology and ${ }^{3}$ General Surgery, Dokuz Eylül University, Faculty of Medicine, IZMiR, TURKEY

\begin{abstract}
Fibroadenoma is the most common breast tumor in adolescent and young women. Fibroadenomas that consist of sclerosing adenosis, papillary apocrine metaplasia, epithelial calcifications, and/or cysts greater than $3 \mathrm{~mm}$ are considered as complex fibroadenoma. The relative risk of developing breast cancer in patients with complex fibroadenoma is increased, compared to women with noncomplex fibroadenoma. Extensive cystic degeneration in a fibroadenoma, so called "cystic fibroadenoma" is very rare. Herein, we present a case of such a lesion in a 43-year-old female who has been on follow-up for fibrocystic changes of the breast, and discuss both radiological and histopathologic differential diagnosis of this lesion with other cystic lesions of the breast, including cystic papilloma. The patient is free of disease after 17 months of clinical follow-up.
\end{abstract}

Key Words: Cystic degeneration, Fibroadenoma, Breast

\section{Öz}

Fibroadenom, adolesan dönem ve genç kadınlarda en sık görülen meme tümörüdür. Fibroadenoma skleroze adenozis, papiller apokrin metaplazi, epitelyal kalsifikasyonlar ve/veya 3 mm'den büyük kistik yapılar eşlik ediyor ise kompleks fibroadenom olarak isimlendirilir. Kompleks fibroadenom olgularında meme kanseri gelişme riski, nonkompleks fibroadenomlara göre daha fazladır. Yaygın kistik dejenerasyon gösteren fibroadenomlar ise "kistik fibroadenom" olarak tanımlanmakta olup, oldukça nadirdirler. Burada, memenin fibrokistik değişiklikleri nedeni ile izlem altında olan 43 yaşındaki bir kadın hastada saptanan nadir bir kistik fibroadenom olgusu sunularak, bu lezyonun kistik papillom gibi memenin diğer kistik lezyonları ile radyolojik ve histopatolojik ayırıcı tanısı tartışılmıştır. Klinik olarak 17 aylık izlem sonucu, hastada herhangi bir rekürrens ya da malignite gelişimi saptanmamıştır.

Anahtar Sözcükler: Kistik dejenerasyon, Fibroadenom, Meme

\section{INTRODUCTION}

Fibroadenoma is the most common breast tumor both clinically and pathologically in adolescent and young women. Cystic changes, usually measuring between $1 \mathrm{~mm}$ to $10 \mathrm{~mm}$, may occur within these benign fibroepithelial tumors. Fibroadenomas that consist of cysts greater than $3 \mathrm{~mm}$, sclerosing adenosis, epithelial calcifications, and/or papillary apocrine metaplasia are considered as complex fibroadenoma (1). It is well known that the relative risk of developing breast carcinoma in patients with complex fibroadenoma is increased, compared to women with noncomplex fibroadenoma (2). Predominant cystic degeneration of the tumor that grossly constitutes most of the tumor, so called "cystic fibroadenoma," is very rare. Herein, we present a rare case of cystic fibroadenoma of the breast in a 43-year-old female.

\section{CASE REPORT}

A 43-year-old female with a history of fibrocystic changes of the breast, presented with a palpable lump in her right breast. She had no family history of breast cancer. Clinical examination revealed a non-tender, mobile, wellcircumscribed cysticlesion in the lower inner quadrant of the right breast. Mammography showed a well-circumscribed mass lesion with thickened wall (Figure 1). On sonography, the mass was hypoechoic and sharply defined, reminiscent of a cystic lesion with thick and irregular wall. The lesion was excised. Gross examination of the specimen showed a sharply demarcated cystic lesion that was $3.3 \times 1.7 \mathrm{~cm}$ in size, with a jelly-like dense homogeneous, dark yellow material in its lumen, reminiscent of galactocele (Figure 2). The thickness of the cyst wall was approximately $3 \mathrm{~mm}$, and the inner surface had papillary foldings reminiscent of cystic papilloma. 


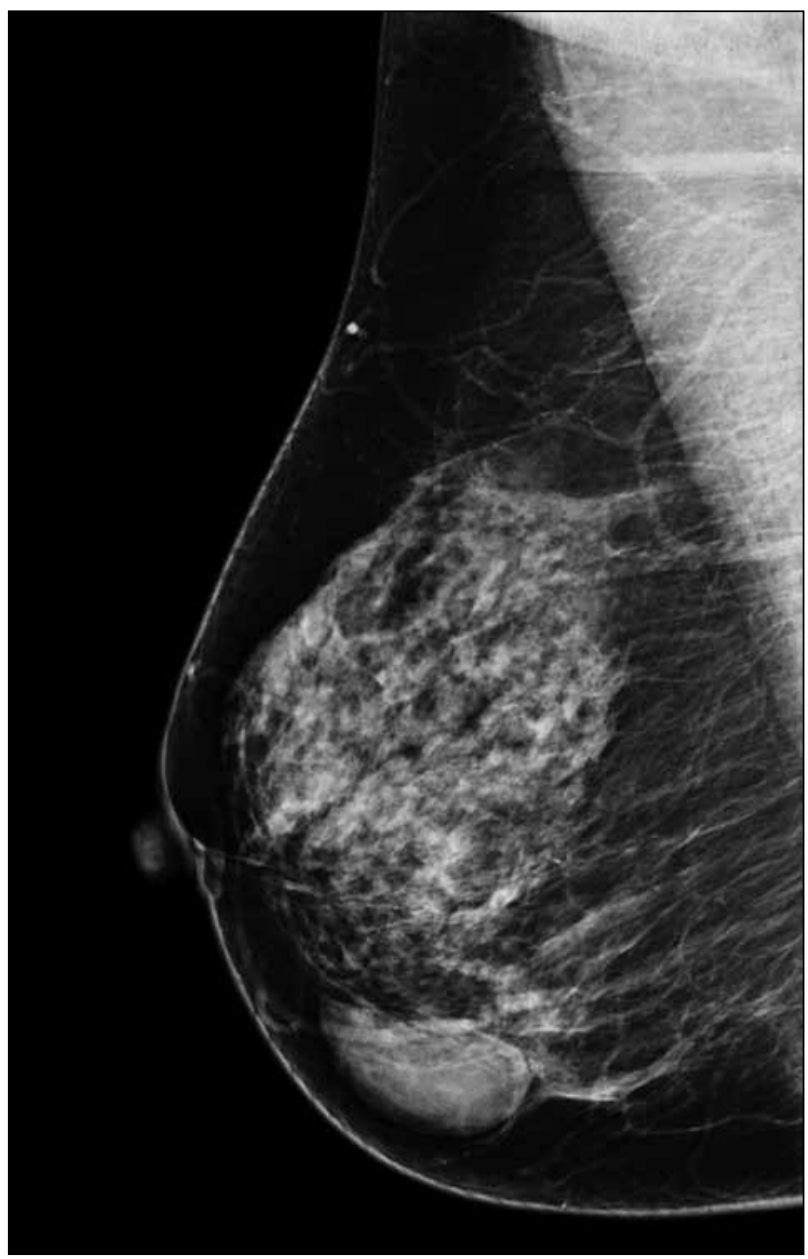

Figure 1: Mediolateral oblique mammogram reveals a solid, ovalshaped, well-circumscribed mass with no calcification.

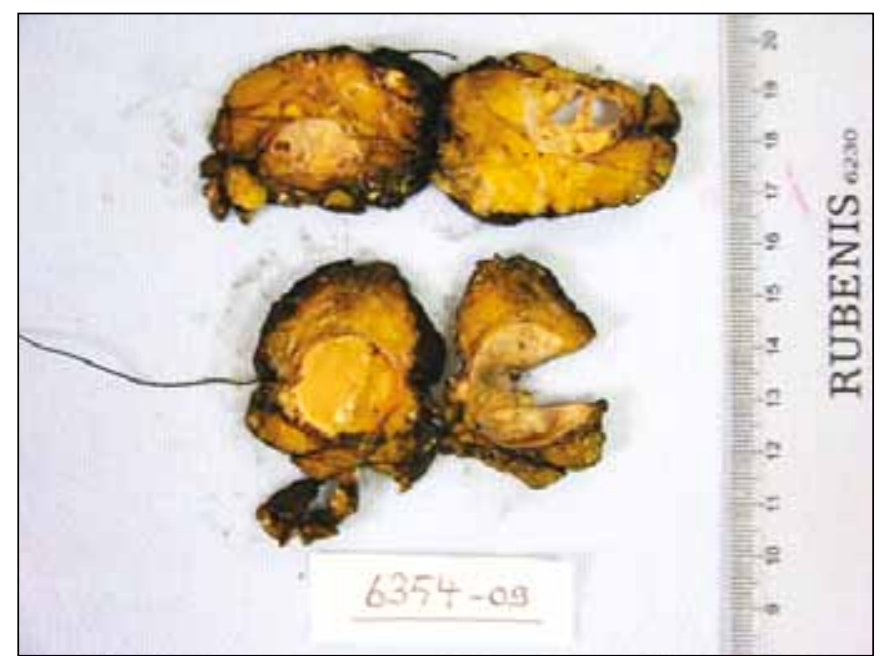

Figure 2: Grossly, this well-circumscribed cystic lesion has a fibrous capsule at the periphery, and a jelly-like, dense, homogeneous dark yellow material in its lumen.
Histologic examination of the lesion demonstrated a cyst filled with dense secretory material that included coarse papillary projections into the cystic cavity. Some areas of the cyst wall had classical fibroadenoma appearance with elongated compressed ducts and stromal proliferation, and some areas showed ducts with apocrine epithelial metaplasia (Figure 3). Surrounding breast parenchyma consisted of fibroadenomatoid nodules. The lesion was diagnosed as cystic fibroadenoma of the breast, and because the largest dimension of the cyst was greater than $3 \mathrm{~mm}$, it was considered as a complex fibroadenoma. The patient is well, and free of disease or recurrences after 17 months of follow-up.

\section{DISCUSSION}

Fibroadenoma is the most common cause of breast lumps in young women. It is a benign fibroepithelial tumor of the breast, composed of both stromal and epithelial components. In most cases, a painless, well-circumscribed, solitary breast lump is detected by self examination of the patient. Over time, this tumor may undergo some degenerative changes, such as myxoid degeneration, metaplastic changes including smooth muscle (myoid) metaplasia, adipose differentiation, rarely osteochondroid metaplasia, or infarction $(1,3)$. In some fibroadenomas, discrete round cysts measuring between $1 \mathrm{~mm}$ to $10 \mathrm{~mm}$ are found. If the tumor has cysts greater than $3 \mathrm{~mm}$, or associated sclerosing adenosis, epithelial calcifications, or papillary apocrine metaplasia, it is considered as complex fibroadenoma. Predominant cystic degeneration of this

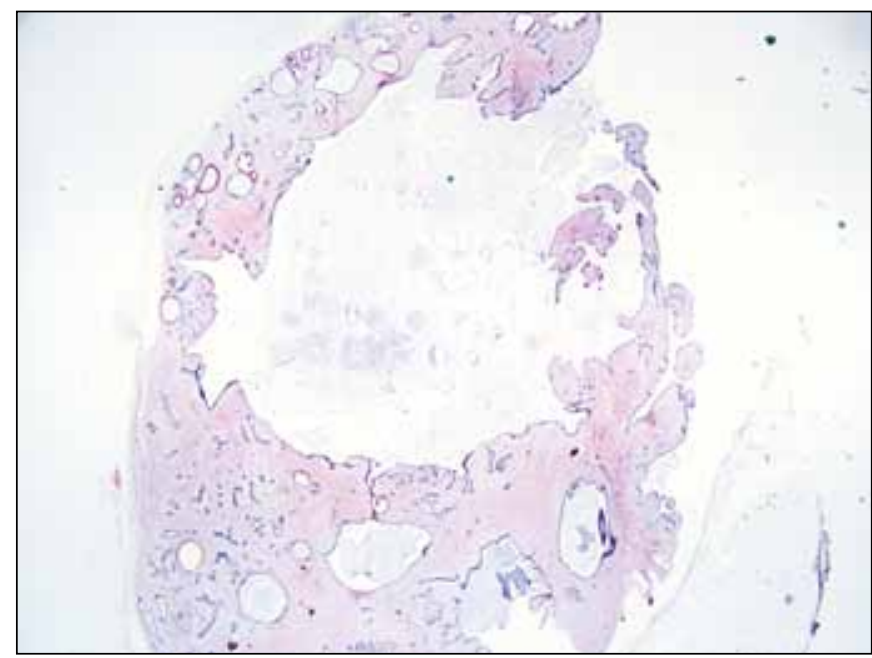

Figure 3: Histologically, the lesion is predominantly cystic. The cyst wall is composed of stromal proliferation and elongated compressed ducts, with some ducts showing apocrine epithelial metaplasia (H\&E; x20). 
tumor is very rare (1). Nevertheless, cystic fibroadenoma, that is thought to arise from ectopic mammary glands have been reported in other organs as well, such as vulva (4) and prostate (5).

In most fibroadenoma cases, mammography reveals a homogeneous, round or oval, circumscribed mass. However, mammography cannot distinguish whether a mass is solid or cystic. Ultrasound examination is usually preferred for characterizing of cystic breast masses. Radiologically, cystic lesions of the breast can simply be categorized as predominantly cystic masses with solid components, or predominantly solid masses with cystic components (6). Predominantly cystic lesions include simple cysts, traumatic and postoperative fluid collections, abscess, galactocele, cystic papilloma and cystic papillary carcinoma. Complex breast cysts, that are defined as cysts with thick walls, thick septa, intracystic masses, or other discrete solid components, include both benign lesions, such as fibrocystic changes, intraductal or intracystic papilloma without atypia, fibroadenoma; atypical or highrisk lesions, such as atypical ductal hyperplasia, atypical papilloma; and malignant lesions, such as ductal carcinoma in situ, invasive ductal and invasive lobular carcinoma $(6,7)$. Clinical, imaging, and pathologic correlation is significant in these lesions for appropriate management of the patient. According to Berg et al, presence of a discrete solid component in a complex cystic mass, or presence of thick wall or thick septations in an otherwise cystic lesion, without antecedent trauma or evidence of infection should suggest possible malignancy and require biopsy. They have found in their series that $23 \%$ of patients with such complex cystic lesions had a diagnosis of malignancy pathologically (8).

Histologically, simple cysts can be divided into two groups according to their cell lining and electrolyte content: epithelial cell-lined cysts and cysts lined with cells that have apocrine metaplasia. The latter group, which is characterized by fluid low in sodium and high in potassium has a tendency to recur after aspiration more commonly than do epithelial cell-lined cysts (6). Galactoceles are cysts that contain milky fluid. They develop in women who are pregnant, lactating, or have stopped lactating within the last 2 to 3 years. Histologically, these cysts are usually lined by cuboidal or flat epithelial cells with cytoplasmic vacuolization due to lipid accumulation $(1,6)$. Papillary lesions, on the other hand, are characterized by branching fronds of fibrovascular stroma protruding into the lumen, lined by epithelial and myoepithelial cells (1). The presence or absence of myoepithelial cells distinguishes benign from malignant papillary lesions.

Various studies have reported that fibroadenomas do not have increased risk for developing breast carcinoma, unless the tumor or the surrounding breast parenchyma shows proliferative changes, or the patient has a family history of breast cancer $(2,9)$. Dupont et al. have reported that the relative risk of developing breast carcinoma was 3.1 for women who had complex fibroadenoma, and that the risk had increased to 3.7 if the patient had complex fibroadenoma and a family history of breast carcinoma (2). Our patient, who did not have a family history of breast cancer, is well and free of disease or recurrences after 17 months of follow-up.

In conclusion, differential diagnosis of cystic lesions of the breast may be difficult both clinically and radiologically. Pathologic examination of the lesion is usually necessary in order to highlight the nature of the lesion. Cystic fibroadenoma, although rarely seen, should be considered in the differential diagnosis of cystic lesions of the breast, that includes cystic papilloma and fibrocystic changes.

\section{REFERENCES}

1. Rosen PP: Fibroepithelial neoplasms. In Rosen PP. (Ed): Rosen's Breast Pathology. 3rd ed., Philadelphia, Lippincott Williams \& Wilkins, 2009, 187-201

2. Dupont WD, Page DL, Parl FF, Vnencak-Jones CL, Plummer WD Jr, Rados MS, Schuyler PA: Long-term risk of breast cancer in women with fibroadenoma. N Engl J Med 1994, 331:10-15

3. Pinder SE, Mulligan AM, O'Malley FP: Fibroepithelial lesions, including fibroadenoma and phyllodes tumor. In O'Malley FP, Pinder SE, Goldblum JR. (Eds): Breast Pathology. 1st ed., Philadelphia, Churchill Livingstone Elsevier, 2006, 109-115

4. Menet E, Wager I, Babin M, Magnin G, Babin P: Multiple vulvar cystic and papillary fibroadenomas. J Gynecol Obstet Biol Reprod 1999, 28:830-832

5. Gerridzen RG, McDonald MW, Mai KT: An unusual pelvic mass: cystic fibroadenoma of the prostate. Can J Urol 1995, 2:172-174

6. Cardenosa G: Cysts, cystic lesions, and papillary lesions. Ultrasound Clin 2007, 1:617-629

7. Doshi DJ, March DE, Crisi GM, Coughlin BF: Complex cystic breast masses: diagnostic approach and imaging-pathologic correlation. Radiographics 2007, 27:53-64

8. Berg WA, Campassi CI, Ioffe OB: Cystic lesions of the breast: sonographic-pathologic correlation. Radiology 2003, 227: 183-191

9. Hutchinson WB, Thomas DB, Hamlin WB, Roth GJ, Peterson $A V$, Williams B: Risk of breast cancer in women with benign breast disease. J Natl Cancer Inst 1980, 65:13-20 